\title{
ІСТОРИЧНІ ВИМІРИ ЕПІСТОЛОГІї
}

\section{Копиця М. Д.}

\section{ВСТУП}

У дев'яності роки минулого століття інтелектуальне суспільство нашої молодої держави почуло пророчі думки Л. Костенко про гуманітарну ауру України, розбудову ії цілісного, не деформованого образу в усьому світі... Минає третє десятиліття, але ми продовжуємо: шукати шляхи між Сцилою i Харібдою, намагаючись увійти в інтеркультурний світовий контекст.

Одна група вчених, політологів, істориків намагається тиражувати i міфологізувати хронічно-стереотипний концепт України, як нездатної перебудувати свій метачас, векторно скерувати його до постмодерної нелінійної темпоральності, у співвідношенні вічності і часу і тим стати в ряд розвинутих країн. Створений образ нас як народу запрограмовано нещасного, з комплексом рабських звичок стояти перед усіма на схиленому до низу поклоні, зі вторинністю бездержавності, «викривленою мовою», культурою, «хатою з краю».

Інша група, навпаки, закликає до вироблення імпульсів, які відповідали б модерній нації, ії справжньому державному статусу. Для кожної нації історія власної присутності у світі дає змогу крізь національне відтворювати універсальне бачити панорамно єдине в багатоманітні, презентувати світу інформаційний потенціал своєї історії, iї духовних запитів. У свою чергу, звернення до символічних образів минулого і сучасності невіддільне від глибокої духовної пам'яті як форми актуалізації культурних смислів.

А для цього потрібно будувати «гуманітарну ауру» нації (Л. Костенко) з ії динамічним, пульсуючим стрижнем життєвої пам'яті, яка - у минулому і теперішньому - осмислюється 3 філософських глибин, об'ємно, багатовекторно, історично правдиво.

Один зі шляхів введення в інтеркультурний світовий контекст - це актуалізація концепту неповторності української нації. Шлях подолання епохи руїни (як це існувало у другій половині XVII століття) відкриє перспективу набуття духовності і зробить Україну суб'єктом історії. Переосмислення досвіду нашої нації в іiі найціннішому духовному спадку, в аспекті відповідей на потреби часу - так минуле стане більш актуальним, i перед світом постане цілісний, не деформований образ українського світу. 
Академік Сергій Кримський не раз стверджував, що в час загострення запитів до європейської цивілізаційності, узагальненого бачення гуманістичних цінностей і ролі національних формул архетипи українського бароко, кордоцентризм Г. Сковороди, екуменізм П. Могили, гуманізм Києво-Могилянської академії, Шевченків образ Христа і «софійність» - такі категорії достойні представляти осердя української духовності.

Погляд «крізь віки» потребує розкриття фактів історії в їх метаісторичному контексті, підключившись до джерел, доля яких складалась непросто. Процеси вивчення розвитку музичного мистецтва невіддільні від питань джерелознавства, адже без вивчення, віднайдення, осмислення фактографічної бази неможливі серйозні наукові узагальнення. Тільки завдяки введенню нових фактичних даних з'являється можливість осягнути цілісну картину історико-художнього процесу.

На сучасному етапі у XXI столітті музично-історична наука переживає напружений етап у своєму розвитку, коли ми стаємо свідками нових, здебільше сенсаційно-приголомшуючих фактів - особливо минулого століття - які кардинально міняють наші уявлення про перебіг музично-історичних процесів. Це викликає бурхливі реакції наукового співтовариства не тільки щодо нових концепційних шляхів осмислення новознайдень, але i повертає дискусії в розмисли над предметом історичного наукового музикознавства, сутності музичних процесів на векторі антропології, психології, культурологічних теорій тощо.

Художньо-історичний процес як феномен теорії історії аналізується в роботах С. Раппопорта, С. Кримського. М. Поповича, О. Самойленко, Л. Кияновської та багатьох інших учених. У сучасному історичному вимірі характер пошуку смислів став якісно іншим, ідея процесуальності історії посіла одне із чільних місць, утверджуючи історичний погляд на музично-мистецькі явища.

«Там, де мовчать джерела, - німа історія, де вони спрощуються спрощується й вона, де вони викривлюються - викривлюється й історична наука» ${ }^{1}$.

Отже, правильно визначені вченими методологічні иляхи дослідження джерел, а також фактографічного наповнення, музичноісторичного процесу є однією з базових позицій джерелознавства як складової частини музикознавчого аналізу.

Ще одним важливим методологічним виміром історико-музичних процесів виділимо проблему періодизаиії історії музики, адже музична культура кожної з епох розвивається завдяки багатьом суб'єктивним i об'єктивним чинникам із тільки їй притаманними ознаками

\footnotetext{
${ }^{1}$ Halpen L. Introductional' Histoir. Paris, 1946. P. 61.
} 
і принципами. Життя музичних творів крізь методологічне скло історичних артефактів, «розчинених» у біографії їхніх авторів - ось реалії, що невідлучні від діяльності митців. Це становить фактологічні матеріали особового походження, за допомогою яких поглиблюються уявлення про перебіг творчого процесу, акцентуються концепційні моменти.

Така інформація відображена в епістоляріях, мемуарах, документах державних i приватних установ, публіцистичних i критичних матеріалах, засобах комунікації. Нарешті, третім методологічним виміром історико-музичних процесів уважаємо антропологічний чинник. Століття, що відійшло в історію, показало образ людини, «яка взята як інтеграл усіх речей, але задовольняється вбранням андерсенівського короля: він став дармограйством, риторичною закарлючкою, він перестав бути <...>»². Важливою проблемою антропосвідомості стала міфотворча позиція, нібито «цінність» людського чинника аксіоматична, але в реальності життя людини перестало щось вартувати, перетворившись у «людський фон». Головним завданням історичної антропології було і залишається відтворення картини світу через реконструкцію суб'єкта в його епосі. На такі оцінки сучасних суб'єкту подій багаті жанри мемуарів та епістоляріїв. На жаль, вчені не виробили механізмів аналізу і методики найсучаснішої інформації в питаннях історико-мистецької хроніки, це залишається актуальним у сучасному науковому світі.

В істориків-джерелознавців поки немає методики праці з відбору фактів із тих чи інших джерел. Одні вчені вважають, що значна частина фактологічного матеріалу у джерелах є зайвою. Так, дослідник школи джерелознавців XIX століття М. Карєєв стверджував, що історик не повинен враховувати абсолютно все, що міститься в джерелі. Він тоді схожий на господаря, який у себе на городі дає волю як бур'янам, так i корисним рослинам.

Інші вчені, навпаки, цінують кожний факт під час здійснення аналітичних операцій. Адже нині інформація здається нібито непотрібною, із часом вона перетворюється на надважливу і корисну. Тому введення до наукового обігу якомога більше фактологічного матеріалу допомагає відтворювати правдиву панораму розвитку мистецьких процесів.

У роботі над аналізом і узагальненням фактологічного матеріалу необхідно брати до уваги такі чинники:

- повторення однорідних фактів, що слугує їх об’єктивації;

2 Свастьян К. Человек как творение и творец культуры. Bonpocbl философии.1987. № 6. 
- виявлення характерних суттєвих змін у розвитку музичноісторичних процесів, що називається статистикою фактів;

- аналіз музично-історичного процесу через музичну подію як серію індивідуальних, багатобарвних і неповторних фактів;

- узагальнення основних координат методики дослідження джерел як процес виокремлення фактів та їх усебічне дослідження.

Отже, y тлумаченні фактів, їх інтерпретацї̈, створенні на иій основі наукової концепиії історико-музичного процесу актуалізується сенс наукового джерелознавчого дослідження.

Ігнорування факту призводить до викривлення, а також сумнівних висновків. Відомо чимало прикладів так званого «редагування» або «скорочення» нібито незначних фактів у публікаціях, особливо епістолярних матеріалів 3 архівів, видатних діячів української культури. Згадаємо листування Б. Гмирі, М. Скорульського, В. Косенка, багатьох інших у 1970-1980-х роках ХХ століття. Як зауважує А. Гулига, учений не має права вільно інтерпретувати документи історичної ваги, якими послуговується в дослідженні.

Переконавшись у достовірності мистецького факту, подавши історично правильне його тлумачення, здійснивши всебічний аналіз, треба бути максимально обережним у подачі аксіологічного виміру історичного явища. Виділимо факти як основоположні, другорядні, фрагментарно подані, розрізнені тощо. Головне, треба виходити 3 різних функційних значень фактів - як події, знання, історичної реалії, інформації, джерела, біографії, музичної структури тощо. Таких типів і видів факту безліч, але головне, що в усіх варіантах фактів відображена не об'єктивна подія, а тільки інформація про неї, яку варто перевірити іншим контекстом.

Важливість і необхідність джерелознавства, а особливо документів особового походження, людство усвідомило далеко не відразу. У музичній науці предметне вивчення джерела як «археологічного універсуму» представляється надзвичайно кропітким, складним, але актуальним завданням. Тільки через джерело як факт історії можна об'єктивно проаналізувати історичне минуле, правильно визначити логіку руху музичної історії.

\section{1. Історичні передумови розвитку джерелознавства}

Джерелознавство як окрема наука становить важливу складову частину національної історії. Кожна нація, яка опрацьовує й осмислює свої джерельні пам'ятки, усвідомлює себе як член співтовариства народів, країн, держав, світу. Потужний поштовх до початку серйозного розвитку історичної археології стався в Німеччині в 1819 році, коли під егідою наукового товариства відомий політикреформатор, один із керівників Пруського уряду Г.Ф. фон Штейн 
розпочав видання серії «Пам'ятки німецької історії». Увесь зібраний матеріал систематизувався за такими розділами:

- Scriptores (історичні джерела);

- Leges (закони, юридичні зібрання);

- Diplomata (документи);

- Epistolae (листи);

- Antiquitates (стародавність).

Пізніше до цього потужного починання долучаються Франція, Австрія, Італія. Історико-джерелознавча наука розвивається в межах шкіл палеографії, дипломатики. Серйозним осередком підготовки архівістів найвищої кваліфікації стала Флоренція.

В Україні джерелознавство як самостійна історична галузь знань започатковане у другій половині XIX століття і пов'язане 3 діяльністю Археографічної комісії, куди входили видатні вчені Університету імені св. Володимира. Паралельно в Харкові й Одесі формувались методологічні фундаментальні бази археологічної науки. Західноукраїнські вчені гуртувались навколо Наукового товариства імені Тараса Шевченка, а із приїздом до Львова Михайла Грушевського джерелознавча школа досягає кульмінаційних злетів, актуалізованих у багатотомних виданнях «Джерела історії України-Руси», «Український архів» тощо. Саме тоді вдосконалюється методика роботи над джерелами, уточнюється категоріально-термінологічний апарат, створюються наукові школи - професорів В. Перетця, Д. Багалія, Д. Яворницького, О. Лазаревського, В. Антоновича й інших. Тоді ж складається база для застосування методологічних параметрів науки в мистецтвознавчій сфері, зокрема музикознавчій.

Трагічні події двох світових війн у ХX столітті боляче вдарили по джерелознавчій науці - ідуть із життя засновники шкіл, переслідуються їхні учні та послідовники, усі процеси штучно перериваються репресивними соціально-політичними акціями. Це призводить до проявів войовничого антиісторизму, що суттєво знижує, а то і гальмує розвиток всього спектра допоміжних дисциплін - мемуаристики, епістології, документознавства, геральдики й інших.

Десятиліття майже повного мовчання боляче вдарили по джерелознавчій галузі. I тільки 3 періодом кінця XX - перших десятиліть XXI століття поетапно відновлювалось підгрунтя для сучасного осмислення комплексу питань методологічного спектра.

Не менш напружена панорама музично-джерелознавчих розробок: не осмислений ланцюг проблем теоретичного, категоріального, класифікаційного порядку, не створена досконала система джерел, що розкидані по різних архівах і сховищах. Серед спеціалістів немає 
одностайності в розумінні термінів (рід, тип, вид музично-історичного джерела, класифікаційні групи і підгрупи).

На сучасному етапі в Україні найбільш потужними є чотири осередки з дослідження джерелознавчих питань:

- відділ джерелознавства НАН України;

- кафедра джерелознавства й архівознавства Національного університету імені Тараса Шевченка;

- кафедра джерелознавства Дніпропетровського університету;

- Головне Архівне управління при Кабінеті Міністрів України.

Результати наукових розробок і досліджень учених зосереджуються у спеціалізованих періодичних виданнях «Український історичний журнал», «Архіви України», «Вісник Київського університету. Історичні науки».

На жаль, у музикознавчій науці поки таких журналів архівноджерельного напряму немає. Хоча дослідження або публікації окремих цінних джерел періодично з'являються. Зазначимо видання листів О. Кошиця, підготовлених Л. Пархоменко, низку публікацій М. Головащенка (О. Кошиць, О. Мишуга, М. Менцинський), численні роботи К. Шамаєвої, листування М. Лисенка, Б. Лятошинського, матеріали і документи В. Косенка, Б. Гмирі та багато інших.

Навіть побіжний огляд архівних фондів у державних і приватних сховищах дає уявлення, наскільки грандіозна робота 3 вивчення й опрацювання даних матеріалів чекає на українських дослідників. Без сумніву, оприлюднення раніше недоступних документів, матеріалів, мемуарів, листування, уведення їх до наукового обігу може змінити або суттєво відкорегувати концепцію музично-історичних процесів в Україні.

На жаль, у музикознавчій науці тільки розпочався процес формування окремої науки - епістології - де би послідовно, в ієрархічній послідовності були розроблені методологічні засади вивчення листа як документа історії з усіма жанровими різновидами від стадії пошуку, розшифрування тексту, редагування, коментування до впровадження в науковий обіг результатів цієї роботи.

Які ж особливості перелічених етапів дослідження епістоли як документа свого історичного часу?

Для відповіді на це питання введемо поняття мікроісторії, на тлі і за законами якої розглянемо «силове поле» суб'єктно-об'єктних взаємозв'язків. Особливості статусу мікроісторії - у можливості відкрити паралельні або альтернативні факти макроісторї. Саме особистість як суб'єкт і носій конкретної оцінки своєї епохи, його сприйняття історико-культурної фактології стануть засадничими чинниками подальших узагальнень. 


\section{2. Концепт перший}

Щоб розшифрувати унікальні епістологічні послання 3 минулого, досліднику необхідно заглибитись у культурний контекст епохи, яка вивчається. Але аналізований контекст треба знати не за академічними даними, а на рівні їх живого перебігу, тобто через знайомство з іншими джерельними документами того часу. Без залучення таких мікроісторичних даних не можуть бути адекватно потрактовані i правильно витлумачені історико-мистецькі факти 3 потрібною глибиною.

Світова музична культура має приклади глибокого, усебічного дослідження життєтворчості видатних митців. Однією з таких постатей $\epsilon$ Й.С. Бах. Вивчення його спадщини триває більше 250 років, і вказати на кількість робіт, яка швидко зростає, майже нереально. Усі великі і малі праці становлять масштабну галузь - бахознавство, важливою складовою частиною якої є документалістика, а матеріали особового походження становлять надзвичайну цінність. Саме завдяки вивченню джерел документального походження відкрились можливості складання найповнішого реєстру документальних матеріалів стосовно життя і творчих опусів митця. А це, у свою чергу, дало можливість ученим вийти на рівень концепційного осмислення історичної місії геніального майстра.

В історії музики відомі приклади, коли після віднайдених епістоляріїв того чи іншого композитора відкривалась перспектива наступної атрибутивної роботи, аналітичних версій чернеткових текстів, встановлення їх автентичності, часу виникнення. Найбільш плідною в цьому напрямі вважаємо діяльність учених-медієвістів В. Металлова, С. Смоленського, М. Фіндейзена, а $з$ українських О. Цалай-Якименко, О. Шреєр-Ткаченко, Ю. Ясиновського, Н. Герасимової-Персидської, їхніх наукових шкіл.

У XX столітті характер аналізу епістоляріїв, як і матеріалів особового походження, представляється дещо іншим. У другій половині минулого століття, під час праці над спадщиною таких геніїв, як I. Стравинський, С. Прокоф'єв, музикознавець Віктор Варунц замислився над питанням: чи можна епістолярій як вид діяльності вважати частиною спадщини митців? Адже доля листувань у $\mathrm{XX}$ столітті була надто драматичною. Дописувачі часто різним чином приховували правду, включали езопову мову, серії натяків, навіть напівправди, а то і брехні. Не секрет, що листи, як свідки подій, ховали, знищували, щоби вони не вплинули на долю їхніх авторів.

Питання важливості вивчення спадщини через листування відпадає само собою, коли починаєш працювати над епістолами і мемуарами 
О. Бенуа, щоденниками С. Прокоф'єва, листуванням С. Прокоф'єва і М. Мясковського, які можна вважати шедеврами своїх жанрів.

Але, розшифровуючи чернетки стенограм виступів того ж С. Прокоф'єва, В. Варунц вимушений був ставити три крапки там, де 3 політичних заборон не мав права друкувати табуйовані прізвища В. Набокова, М. Ростроповича, К. Кондрашина, Г. Вишневської і навіть М. Хрущова, який теж перебував у цензурній опалі.

До 1960-х років XX століття інформація про життєтворчість Франсіса Пуленка 3 різних причин була недоступна радянському читачеві і слухачеві. Невдовзі в російському перекладі вийшли листи Ф. Пуленка: із 226 епістол 132 - самого композитора, 94 - від друзів, родичів, знайомих. Фактологічний матеріал листів надзвичайно цінний. У ньому відображено життя Парижа 1920-1940-х років, зафіксовані стосунки «групи шести», факти культурних процесів тодішньої мистецької Мекки світу. Це зробило видання листів надзвичайно цінним історико-мистецьким об'єктом, джерелом важливої інформації 3 різних питань культури.

Цікавими «сигналами 3 минулого» уважаємо 25 листів Д. Шостаковича до І. Блажкова, у яких охоплено десять років творчого спілкування молодого диригента 3 Метром (1964-1975 роки). I. Блажков виконав цілу низку творів Д. Шостаковича, Другу, Третю симфонії, сюїту з опери «Ніс» та багато інших, реабілітував їх після років забуття і нищівної критики.

\section{3. Концепт другий}

Пов'язаний із з'ясуванням причин та умов створення джерела листа.

Судження і думки суб'єктів, які живуть в одну епоху, в тих самих умовах, можуть суттєво різнитися як за повнотою подачі факту, так і за достовірністю інформації. Ці реалії мають особливо велике значення у XX столітті на теренах складних соціально-політичних та багатьох інших обставин.

Епістола - феномен культури свого часу, явище інтерсуб 'єктивного спілкування. На цьому основному етапі дослідження вирішуються такі завдання:

- ретельне ознайомлення з історико-культурною ситуацією;

- інтерпретування джерела-епістоли на рівні тих соціальних, культурних умов і обставин, у яких писалась кореспонденція;

- аналіз джерела-епістоли, його стилістики, особливостей авторського літературного стилю, змістової суті.

Концепт третій передбачає аналіз багатофункціональних зв'язків епістолярного жанру. 
На цьому рівні узагальнення лист як чинник поповнення історикокультурної панорами свого часу висвітлює i важливі елементи культури, а також представляє творчі портрети сучасників дописувача, суттєві сторони їхніх особистих характеристик.

Багатий епістолярний матеріал представляе постать Тихона Хреннікова - композитора, культурно-громадського діяча другої половини XX століття на соціокультурному та політичному просторі колишнього СРСР. Постать Т. Хреннікова надзвичайно складна і різноаспектна. Темні і світлі сторони багаторічної діяльності цього митця, риси його керівної роботи у Спілці композиторів на тлі авторитарного політичного режиму (1940-1990 роки), уміння «балансувати» на вагах історичних і культурних подій зробили Т. Хреннікова свого роду унікальною фігурою тієї складної радянської доби.

Епістолярні матеріали особового та державного походження, вміщені у книзі «Так это было» ${ }^{3}$, дають уявлення про мистецьке життя та культуру величезного періоду від кінця 1940-х, коли «опіка» партійних органів над мистецтвом була нестерпною, аж до 1990-х років, коли країна постала перед прірвою фізичного, морального, духовного та політичного розвалу. Листи I. Стравинського, С. Прокоф'єва, В. Лютославського, Д. Шостаковича й інших непересічних особистостей до Т. Хреннікова спонукають до роздумів щодо «правди і кривди» у час безпардонного, грубого втручання у справи музичного мистецтва, в особисте життя митців, невиправдані заборони і фальсифікації.

Щодо української панорами особових фондів видатних діячів, то така інформація практично не введена до наукового обігу, сам матеріал практично не досліджений. Причин багато. Одна 3 головних величезний обсяг матеріалів. Їх вивчення потребує комплексного підходу і залучення спеціалістів різноманітних знань.

Друга причина - необхідність глибокого неупередженого дослідження життя i творчості самих фондоутворювачів. Навіть біографічні дані про цих осіб розпорошені в різних джерелах, спотворені тенденційними тлумаченнями, загублені або знищені органами КДБ.

I, нарешті, третя причина - труднощі з розшифруванням рукописів, потреба в поясненні численних імен, фактів історії, характеру людських стосунків, що часом приховані між рядками мимоволі чи навмисне. Значення таких документів важко переоцінити, але насамперед включити до реєстрів музичної історії.

У більшості унікальними видаються маловідомі архівні документи Центрального державного архіву-музею літератури i мистецтва

3 «Так это было». Тихон Хренников о времени и о себе. Москва : Музыка, 1994. C. 205. 
України, у якому налічується більше трьох сотень цілісних архівних справ особистого походження, серед яких музиканти займають вагомі статистичні позиції - майже третю частину від загальної кількості одиниць зберігання.

Серед діячів музичного мистецтва в переліку архівів фондоутворювачів представлені видатні українські співаки: М. Ворвулєв, Б. Гмиря, М. Донець, М. Донець-Тесейр, I. Паторжинський, М. Литвиненко-Вольгемут， О. Петрусенко， Л. Руденко, Л. Собінов, 3. Гайдай. Епістолярний спадок митців - це листування Б. Гмирі 3 О. Вишнею, І. Козловським, Ю. Смоличем, Д. Шостаковичем.

Вагомий внесок епістоляріїв П. Козицького - спілкування 3 К. Данькевичем, Ф. Колесою, Л. Ревуцьким, Б. Яворським, П. Тичиною, М. Рильським, іншими. Інформація 3 епістол суттєво доповнює наші знання про трагічні сторінки життя і творчості митців. Так, необхідний матеріал для відтворення історії арешту і вбивства М. Донця в катівнях НКВД міститься в його справі в архіві Служби безпеки України. Але листування М. Донця із дружиною, кореспонденції до М. Рильського, О. Вишні закривають деякі крапки над «і» у трагічній долі видатного українця-патріота.

Потужним видається архівний список особових фондів українських композиторів - А. Кос-Анатольського, Ю. Мейтуса, С. Людкевича, Ф. Надененка, В. Польового, О. Сандлера, Ю. Рожавської, В. Косенка та багатьох інших. Найбільшими за обсягом $є$ архівні фонди Ю. Мейтуса та К. Данькевича.

Могутня і масштабна постать К. Данькевича (1905-1984 роки) віддзеркалена в такому ж багатогранному і фундаментальному архіві, який розосереджений між приватною квартирою й архівом-музеєм ${ }^{4}$. Крім нотної літератури, у музеї зберігаються вірші, нариси, щоденники, літературні твори. У кореспонденціях, адресованих фондоутворювачу, великою мірою віддзеркалено масштабність і широту творчої натури цієї непересічної i, на жаль, малодослідженої особистості. Серед адресатів митця - Р. Щедрін, Д. Ойстрах, М. Рильський, Б. Лятошинський, М. Колеса й А. Хачатуря, Р. Гліер та багато інших митців.

«Искренне скажу, что полюбил тебя очень глубоко, много думая о тебе, о твоем пути, о музыке, где чувствуется неисчерпаемый оптимизм, восторженность и вера в человека, - так починає свого листа Натан Рахлін до К. Данькевича. - Я забрал все партитуры твоей музыки

4 Фонд К.Ф. Данькевича // Центральний державний архів-музей літератури і мистецтва України. Ф. 1299. Оп. № 1. Інв. № 3095/2. 
домой и буду искать в них «зерно» <..> Ты услышишь, как через несколько недель прозвучит «Отелло»» 5 .

Так яскраво, оригінально відгукується на мистецькі задуми видатного композитора видатний диригент XX століття М. Рахлін, обіцяе йому «снова стать твоим дирижером». Не менш яскраво висловлюється про лекторсько-публіцистичний талант К. Данькевича Родіон Щедрін: «<..> Смотрел по телевизору передачу о Гришко, которую Вы вели - и вели на редкость содержательно, взволнованно, с открытой любовью к предмету Вашего разговора. Ваше волнение передалось к нам, зрителям. Чаще бы видеть такие передачи» ${ }^{6}$.

Особливо цікаві факти відображені в листуванні К. Данькевича із другом, одеситом Д. Ойстрахом - це інформація про прем'єрні твори, знакові концерти, турбота про талановиту молодь, яка вже стає на самостійний шлях у мистецтві і працює по всьому світу.

Відомо про драматичні колізії оперного доробку композитора, зокрема його визначного твору - опери «Богдан Хмельницький», яка зазнала незаслуженої нищівної критики партійних органів. К. Данькевич надзвичайно драматично переживав несправедливий удар по опері. Тож беззаперечно важливим став для композитора позитивний відгук про інший його твір - оперу «Назар Стодоля». Висока оцінка твору зафіксована в листі-підтримці від Б. Лятошинського, який рекомендує оперу до постановки як високопрофесійний твір видатного колеги: «<..> нахожу, что она (опера «Назар Стодоля») заслуживает к себе самого пристального внимания и безусловно должна быть включена в репертуар нашими театрами $<\ldots>$ Драматургия его дала большие возможности композитору написать сильное эмоциональное произведение, насыщенное, с одной стороны, мягкой, теплой лирикой, а с другой стороны, напряженными драматическими кульминациями» ${ }^{7}$.

Як бачимо, побіжний огляд деяких архівних справ Центрального державного архіву-музею літератури і мистецтва України свідчить про наявність надзвичайно масштабних і цінних матеріалів, які становлять високий духовний та інтелектуальний пласт вітчизняного музичнокультурного надбання.

5 Лист Н. Рахліна до К. Данькевича від 21 січня 1950 року // Центральний державний архів-музей літератури і мистецтва України. Ф. 1299. Оп. 1. Спр. 146.

6 Лист Р. Щедріна до К. Данькевича від 25 жовтня 1976 року // Центральний державний архів-музей літератури і мистецтва України. Од. Зб. 154.

7 Лист Б. Лятошинського до К. Данькевича б/д. Початок 1950 року // Центральний державний архів-музей літератури і мистецтва України. Ф. 1299. Оп. 1. Спр. 121. 
Але не тільки вітчизняні фонди мають у своїх арсеналах безцінні джерельні пам'ятки. Вони розкидані по всьому світу - від Національної бібліотеки Вашингтону, архіву Товариства імені Тараса Шевченка Нью-Йорка, бібліотеки імені С. Петлюри в Парижі, архівах Варшави, Лондона. Сіднея, Петербурга, Праги... Крім державних, матеріали особового походження наявні в безлічі приватних зібрань і колекцій, які, на відміну від територій колишнього СРСР, дбайливо зберігаються нащадками по всьому світу. Серед матеріалів $\epsilon$ особливі джерельні скарби національного значення. Виділимо дві унікальні пам'ятки листи М. Лисенка та Б. Лятошинського, друк яких реалізовано.

Донедавна дослідники вважали, що джерельних матеріалів, пов'язаних із творчістю та життям Майстра, збереглося небагато, крім невеликого двочастинного збірника (укладачі $\mathrm{H}$. Матусевич та Л. Грисенко $)^{8}$. Вивчення спадщини Митця проєктували у площині історико-теоретичних проблем.

Але у 2002 році світ побачила значна частина листувань Б. Лятошинського і його вчителя Р. Гліера. Матеріали охоплюють період більше півстоліття: перші листи датовані 1914 роком, а останній - 1956 роком. До цих майже 500 листів додамо віднайдені кореспонденції до А. Дмитрієва, М. Мясковського, Д. Шостаковича, Г. Бацевич, диригента Є. Мравінського, інших. На останньому листі стоїть дата «1967 рік». У цей часовий проміжок фактично вмістився майже весь плідний шлях великого композитора. Трагічними віхами в житті та творчості його покоління стали світові війни, революційні заколоти з їх напруженим перебігом подій, стражденні 30 -ті, голодні 40-і, відлигові 50-і та сповнені надії 60-і роки.

Матеріали правдиво окреслюють різні сторони життєтворчості великого Майстра, його світосприйняття, дозволяють з'ясувати малознані факти біографічного шляху, які так чи інакше резонують 3 історико-соціальними подіями епохи. В епістолярії відкриваються досі незнані епізоди стосунків композитора 3 колегами, державними інстанціями, проливається світло на функціонування такої неоднозначної організації, як Спілка композиторів, i, головне, даються точні відомості про історію і дату створення, виконання, подальшу долю багатьох творів Митця.

Листи Б. Лятошинського до Р. Гліера зберігаються в Москві, в Російському державному архіві літератури і мистецтва (РГАЛИ), фонд 2085 , який і досі не є загальнодоступним. Тому публікація їх в Україні була надзвичайно позитивно сприйнята науковими мистецькими

8 Лятошинський Борис. Воспоминания. Письма. Материалы. Киев : Музична Україна, 1986. Т. I, II. С. 243. 
колами. На сучасному етапі перший том листувань, як архівний документ, використовується в десятках наукових праць - дисертацій, монографій, музикознавчих статей.

Епістолярій Б. Лятошинського - Р. Гліера витриманий у традиціях романтичного стилю писемності XIX століття. Саме тоді любили i вміли писати, було прийнято складати довгі, відверті листи. Автори детально викладають свої думки і почуття, глибоко і неупереджено оцінюють події, які відбувалися. Саме в характері такої щирої розмови, чесної і прямої, розгортаються події драматичного, але яскравого життя непересічних особистостей.

Під час опрацювання епістолярних матеріалів дослідник потрапляє в незвіданий віртуальний світ, який існує за своїми, тільки йому притаманними законами. Це особливий вид науки, який вимагає не просто глибокого знання предмета дослідження, а цілковитої віддачі. Важлива якість вченого-епістолога - уміння входження в ситуацію i майже реального в ній перебування, здатність відчути внутрішні причини того чи іншого явища, яким би малодоступним воно не здавалося. У роботі над епістолярними матеріалами 3 надзвичайною ясністю усвідомлюється існування безмежної кількості світів, кожен лист здатний переносити дослідника в нову віртуальну дійсність.

Історична або мистецька подія, яка вже сталася, не переходить в абсолютне небуття. Вона продовжує жити - i не тільки у свідомості індивідуумів, а й у матеріальних об'єктах. Минуле визначає теперішнє, являє собою основу, на якій розгортатимуться події майбутнього. Ще М. Гоголь стверджував, що сутність у минулому. Людство не може відмовитись від минулого, навіть якщо воно забуде його. Минуле вторгнеться в його життя. Адже історія - це пам'ять, яка тримає i відтворює все, що людство вважає і дорогим, і ненависним. Минуле живе у створеній людьми культурі, у людських стосунках і взаєминах, соціально-політичному устрої, традиціях.

\section{ВИСНОВКИ}

Якби історія, уважають учені, позбулася джерел, фактів i аргументів, вона перестала би бути наукою. У великій картині історико-фактологічного знання джерела особового походження мають свій, індивідуальний статус. Неповторність індивідуального колориту в описанні подій i фактів, окремих історично значущих, відомих особистостей дають можливість досліднику змоделювати такі деталі, які не можна знайти у джерелах іншої спрямованості.

Радість від роботи з пожовклим від часу папірцем недописаних нотаток, фрагментом покресленого нотного аркуша може зрозуміти тільки той, хто навчився входити до чарівної країни віртуального 
минулого, переживаючи зафіксовані в листах фрагменти життя дописувачів, страждаючи і переживаючи разом із ними, розмірковуючи над тими чи іншими обставинами їхнього життя чи творчості.

Тільки безмежно поважаючи ту чи іншу особистість митця, можна годинами просиджувати над сторінками пошкоджених невблаганним часом листів, з лупою читати нерозбірливий почерк, шукаючи в тексті логічне наукове пояснення.

На жаль, у музикознавчій науці не сформувалась окрема наука епістологія, де б розроблялись методологічні засади у вивченні листа як документа історії, з усіма жанровими різновидами - від стадії пошуку, розшифрування, редагування, коментування до впровадження в науковий обіг результатів роботи.

Подальший розвиток комунікативних технологій може диктувати різні, часом непередбачувані, варіанти розвитку. Але, безсумнівно, духовний ландшафт багатовікового існування епістоли залишив по собі настільки значущий культурний простір, осмислення якого вистачить до наступних періодів спалаху відродження епістоли в невідомій сьогодні формі. Вхід в історико-культурну тінь означає факт людського спілкування, аури діалогу на відстані, історії.

\section{АНОТАЦІЯ}

Стаття присвячена теоретико-методологічним питанням епістології як частини науки джерелознавства. У бібліотеках, архівах, музеях України зберігаються велика кількість епістологічних матеріалів, які становляють унікальні пам'ятки культурної пам'яті нації, народу, держави. Велика частина епістологічних матеріалів актуалізується в музичних архівних джерелах. У статті відкриваються матеріали архівів видатних українських композиторів Б. Лятошинського, К. Данькевича, диригента І. Блажкова в листуванні з Д. Шостаковичем, російського музичного діяча і композитора Т. Хреннікова, Р. Гліера у зв'язках 3 вітчизняними митцями тощо.

У статті порушується питання щодо сенсу музичного джерелознавства в «людському вимірі» для актуалізації питання теоретичної моделі епістології як частини джерелознавства, точніше, джерел особового походження. В українських архівах, бібліотеках, музеях накопичено велику кількість епістологічних матеріалів, що природно викликає потребу напрацювання теоретико-методологічної моделі аналізу безцінних пам'ятників музично-історичної науки. Для узагальнення теоретичної моделі щодо епістології як складової частини джерелознавства, важливими залишаються три основоположні позиції: питання періодизації історичного процесу, його антропологічні виміри та фактологічний аналіз джерела-епістоли. 
Неповторність індивідуального колориту в описанні подій і фактів, окремих історично значущих, відомих особистостей дають можливість досліднику змоделювати такі деталі, які не можна знайти у джерелах іншої спрямованості.

Але не тільки вітчизняні фонди мають у своїх арсеналах безцінні епістологічні пам'ятки. Вони існують у всьому світі - від Національної бібліотеки Вашингтону. Парижа, Берліна, архівах Варшави, Лондона. Сіднея, Петербурга і Москви, бібліотеки імені С. Петлюри в Парижі, Празьких архівах тощо.

На жаль, у музикознавчій практиці не сформувалась окрема наука епістологія, де б розроблялись методологічні засади у вивченні листа як документа історії, з усіма стадіями вивчення - від пошуку, розшифрування, редагування, коментування до впровадження в науковий обіг результатів.

Правильно визначені вченими методологічні шляхи дослідження джерел-епістол, а також фактографічне їх наповнення в аспекті музичної історії є базовою позицією епістології як складової частини музичного аналізу.

У роботі над узагальненням віднайденого i розшифрованого матеріалу необхідно брати до уваги такі чинники, як:

- повторення однорідних фактів, що слугує їх об’єктивації;

- аналіз музично-історичного процесу через музичну подію;

- виокремлення новознайдених фактів і їх актуалізація.

Переосмислення досвіду нашої нації в іії найціннішому духовному спадку допоможе представити перед світом цілісний, правдивий, не деформований образ українського світу в його барокових архетипах, 3 кордоцентризмом Г. Сковороди, екуменізмом П. Могили, гуманізмом Києво-Могилянської академії, Шевченковим образом Христа, нарешті, ідеєю софійності, яка так чітко простежується й у джерельних, епістологічних практиках.

\section{SUMMARY}

The article is devoted to theoretical and methodological issues of epistology as a part of science related to the study of authentic sources. In libraries, archives, museums of Ukraine there is a large number of epistological materials that represent unique monuments of cultural memory of our nation, people, state. Most of the epistological materials are actualized in musical archival sources. The article opens the archives of prominent Ukrainian composers such as B. Lyatoshynsky, K. Dankevych, conductor I. Blazhkov and their correspondence with D. Shostakovich, Russian musician and composer T. Khrennikov and R. Glier, their relations with domestic artists and attitude towards them. The uniqueness of individual 
color in the description of events, facts as well ashistorically significant outstanding personalities give the opportunity to the researcher to model and restore such details and circumstances that can not be found in sources of another provenance.

But it is not only domestic foundations that have invaluable epistological monuments in their arsenals. They exist all over the world - from the National Library of Washington. Paris, Berlin, the archives of Warsaw, London. Sydney, St. Petersburg and Moscow, the Petliura Library in Paris, the Prague Archives, etc.

Unfortunately, in musicological practice there is no separate science of epistology, which would develop methodological principles in the study of writing testimony source as a document of history, with all stages of study: from search, decoding, editing, commenting to implementation in scientific circulation of results.

Correctly defined by scientists the methodological ways of studying the sources-epistles, as well as their factual content in terms of music history is the basic position of epistology as a component of musical analysis.

In the work on the generalization of the found and deciphered material it is necessary to take into account the following factors:

- repetition of homogeneous facts, which serves to objectify them;

- analysis of the musical-historical process through a musical event;

- separation of newly discovered facts and their actualization.

Rethinking the experience of our nation in its most valuable spiritual heritage will help to present to the world a holistic, true, undistorted image of the Ukrainian world in its baroque archetypes, cordocentrism by G. Skovoroda, ecumenism by P. Mohyla, humanism in Kyiv-Mohyla Academy, Shevchenko's image of Jesus Christ, finally in native idea of philology, which is so clearly traced in both source and epistological practices.

\section{ЛІТЕРАТУРА}

1. Варунц В. Неизвестные материалы в базельском архиве. И.Ф. Стравинский. Сборник статей : научные труды Московской консерватории. Москва, 1997. Сб. 18. С. 142-204.

2. Гмыря Б. Статьи. Воспоминания. Материалы : в 2-х т. Музыка, 1998. $238 \mathrm{c}$.

3. Данькевич К. Щоденник // Центральний державний архів-музей літератури і мистецтва України. Фонд К. Данькевича. Ф. 1999. Оп. 1. Одиниці зберігання 154, 146, 121.

4. Інтерв'ю з І. Блажковим. Дзеркало тижня. 5 жовтня 1996 р.

5. Костенко Л. Гуманітарна аура нації або дефект головного дзеркала : лекція, прочитана в Національному університеті 
«Києво-Могилянська академія», 1 вересня 1999 р. Київ : ВД «КМ “Academia”", 1999. 32 c.

6. Кримський С. Заклики духовності XXI століття. Київ : ВД «КМ “Academia”», 2003. $30 \mathrm{c}$.

7. Прокофьев С.С. и Мясковский Н. Переписка. Москва : Сов. композитор, 1977. $597 \mathrm{c.}$

8. Спеціальні галузі історичної науки : збірник статей на пошану М.А. Варшавчика. Київ, 1999. 211 с.

9. Тарле Е. Значение архивных документов для истории. Вопросы архивоведения. 1961. № 3. С. 101-106.

10. Фонд Б. Гмирі // Центральний державний архів-музей літератури і мистецтва України. Ф. 443. Оп. 1. Од. зб. 64.

11. Фонди М. Донця та М. Донець-Тессейр // Центральний державний архів-музей літератури і мистецтва України. Ф. 122. Оп. 1, 2.

12. Фонд К. Данькевича // Центральний державний архів-музей літератури і мистецтва України. Ф. 1299. Оп. 1. Од. зб. 140, 154, 121.

13. Halphen L. Introduction a l'Histoire. Paris, 1976. 61 p.

14. Самойленко O. Инновационные аспекты современного музыкознания. Украӥнське музикознавство. Київ, 2004. Вип. 33. C. 424-438.

15. Кияновська Л. Музична антропологія і ії перспективи в сучасній гуманітарній науці. Вісник Національної академії керівних кадрів культури і мистеитва : науковий журнал, 2019. № 1. С. 231-235.

\section{Information about the author:} Kopytsia M. D., Doctor of Art History, Professor, Honored Worker of Education of Ukraine, Head of the Department of History of Ukrainian Music and Musical Folklore Ukrainian National Tchaikovsky Academy of Music 1-3/11, Architect Gorodetsky str., Kyiv, Ukraine 